Wydziat Nauk Ekonomicznych i Zarzadzania UMK

Katedra Ekonometrii i Statystyki

Elżbieta Szulc

\title{
ANALIZA STRUKTURY EKONOMICZNYCH PROCESÓW PRZESTRZENNYCH NA PRZYKŁADZIE PKB W WYBRANYCH KRAJACH EUROPEJSKICH
}

Z arys treści. Artykuł prezentuje procedurę budowy ekonometrycznego modelu przestrzennego na przykładzie PKB w wybranych krajach europejskich. Procedura ta nawiązuje do zasady, stosowanej w ekonometrii dynamicznej, według której podstawą modelowania procesu ekonomicznego jest odkrycie jego wewnętrznej struktury i własności. W artykule wyodrębniono deterministyczne i stochastyczne składniki badanego procesu i uzasadniono potrzebę ich uwzględnienia w konstruowanym modelu.

Słow a kluczowe : trend przestrzenny, autokorelacja przestrzenna, macierz powiązań, korelogram.

\section{WPROWADZENIE}

Odkrywanie składnikowej struktury analizowanych procesów jest podstawą ich modelowania. Nie ma przy tym znaczenia, czy rozważa się procesy dynamiczne, czy też procesy przestrzenne. Ponieważ dynamicznym aspektom przebiegu zjawisk poświęcono zdecydowanie więcej uwagi, w niniejszym opracowaniu skoncentrowano się na aspekcie przestrzennym. A zatem przedmiotem rozważań będą ekonomiczne procesy przestrzenne.

Każdy taki proces można potraktować jako funkcję $Y(\mathbf{s}), \mathbf{s} \in D \subset R^{2}$. Metodologia badania procesu przestrzennego opiera się na konstrukcji modelu, który reprezentuje mechanizm generujący dane, tj. realizacje badanego zjawiska. Symbolicznie można zapisać (np. Schabenberger \& Gotway, 2005), iż:

Dane $=$ Struktura + Błąd. 
Najbardziej ogólne modele przedstawiają dekompozycje procesu stochastycznego na część opisującą strukturę deterministyczną procesu w postaci średniej $E[Y(\mathbf{s})]$ oraz część dotyczącą struktury stochastycznej, opisującą wariancję oraz kowariancję procesu.

Koncentracja uwagi na tych składowych ma na celu podkreślenie ważnych własności procesu, tj. stacjonarności (jednorodności) z jednej strony i niestacjonarności (niejednorodności) z drugiej.

Stacjonarność (jednorodność) w szerszym sensie - bo jedynie o takiej w praktyce możemy mówić - wymaga, po pierwsze, stałości średniej, tj. $E[Y(\mathbf{s})]=\mu=$ constans. Jeśli średnia procesu zmienia się wraz z lokalizacją, czyli $E[Y(\mathbf{s})]=\mu(\mathbf{s})$, wtedy zmiany te, czyli $\mu(\mathbf{s})$ utożsamia się z trendem.

Można zatem zapisać następującą formułę modelową dla procesu Y(s):

$$
Y(\mathbf{s})=P(\mathbf{s})+\eta(\mathbf{s}),
$$

gdzie $P(\mathbf{s})=E[Y(\mathbf{s})]$

Wariancja oraz kowariancja procesu $\mathrm{Y}(\mathrm{s})$ jest reprezentowana przez stochastyczne własności procesu $\eta(\mathrm{s})$. Z wcześniejszych ustaleń wynika, że $\mathrm{E}[\eta(\mathbf{s})]=0$. Dla stacjonarnych (jednorodnych) procesów wariancja jest stała względem lokalizacji. Związki między wartościami procesu w różnych lokalizacjach tworzą określone struktury powiązań przestrzennych i jeśli można przyjąć, że owe korelacje zależą jedynie od odległości między lokalizacjami, to pozostaje to w zgodzie z kolejnym aspektem stacjonarności (jednorodności) - w tym wypadku również izotropowości - procesu przestrzennego.

W dalszej części artykułu stawia się hipotezę, że ekonomiczne procesy przestrzenne zazwyczaj nie są stacjonarne (jednorodne) ze względu na średnią. A zatem idei stacjonarności przestrzennej nie należy wiązać $\mathrm{z}$ własnościami ekonomicznego procesu $Y(\mathbf{s})$, a co najwyżej z własnościami procesu $\eta(\mathbf{s})$, które jednak również powinny być odpowiednio zbadane.

\section{CZY W GOSPODARCE ISTNIEJĄ TRENDY PRZESTRZENNE?}

W celu identyfikacji trendu przestrzennego można zaproponować wykorzystanie wielomianowych funkcji dwuwymiarowych. Ogólna postać modelu trendu jest następująca:

gdzie:

$$
P\left(\mathbf{s}_{i}\right)=\sum_{k=0}^{p} \sum_{m=0}^{p} \theta_{k, m} x_{i}^{k} y_{i}^{m},
$$

$\mathbf{s}_{i}=\left[x_{i}, y_{i}\right]$ - współrzędne położenia na płaszczyźnie, $i=1,2, \ldots, N-$ indeksy badanych jednostek przestrzennych, 
$k+m \leq p$,

$p-$ stopień wielomianu trendu.

W praktyce wykorzystuje się trendy stopnia pierwszego, drugiego bądź trzeciego, to jest:

1) trend liniowy:

2) trend kwadratowy:

$$
P\left(\mathbf{s}_{i}\right)=\theta_{0,0}+\theta_{1,0} x_{i}+\theta_{0,1} y_{i}
$$

$$
P\left(\mathbf{s}_{i}\right)=\theta_{0,0}+\theta_{1,0} x_{i}+\theta_{0,1} y_{i}+\theta_{1,1} x_{i} y_{i}+\theta_{2,0} x_{i}^{2}+\theta_{0,2} y_{i}^{2},
$$

3) trend trzeciego stopnia:

$$
\begin{array}{r}
P\left(\mathbf{s}_{i}\right)=\theta_{0,0}+\theta_{1,0} x_{i}+\theta_{0,1} y_{i}+\theta_{1,1} x_{i} y_{i}+\theta_{2,0} x_{i}^{2}+\theta_{0,2} y_{i}^{2} \\
+\theta_{2,1} x_{i}^{2} y_{i}+\theta_{1,2} x_{i} y_{i}^{2}+\theta_{3,0} x_{i}^{3}+\theta_{0,3} y_{i}^{3} .
\end{array}
$$

Parametry modeli typu (2) szacuje się klasyczną metodą najmniejszych kwadratów. Weryfikacji takiego modelu dokonuje się w taki sam sposób jak w przypadku modelu jednowymiarowego.

\section{Przyklad empiryczny}

Badaniu poddano kształtowanie się PKB (w mln euro wg parytetu siły nabywczej) per capita w 2004 roku w sześciu krajach europejskich. Były to: Austria, Niemcy, Czechy, Polska, Słowacja oraz Wegry. Mapa 1. przedstawia badany obszar.

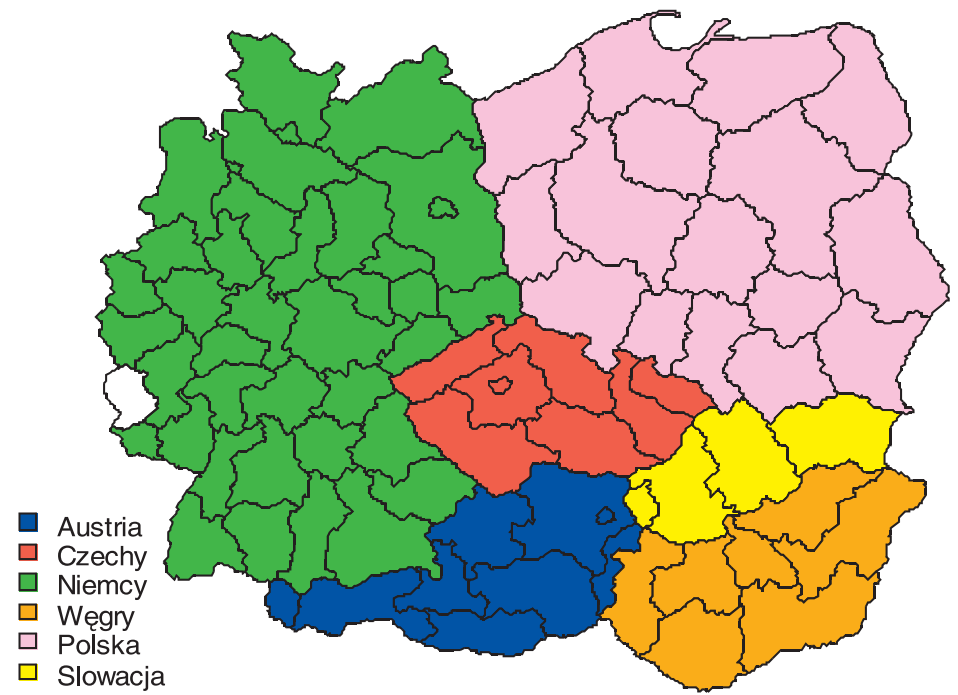

Mapa 1. Regiony wybrane do badania według przynależności do krajów Źródło: opracowanie własne na podstawie danych w odpowiednim formacie, za: Kopczewska (2006). 


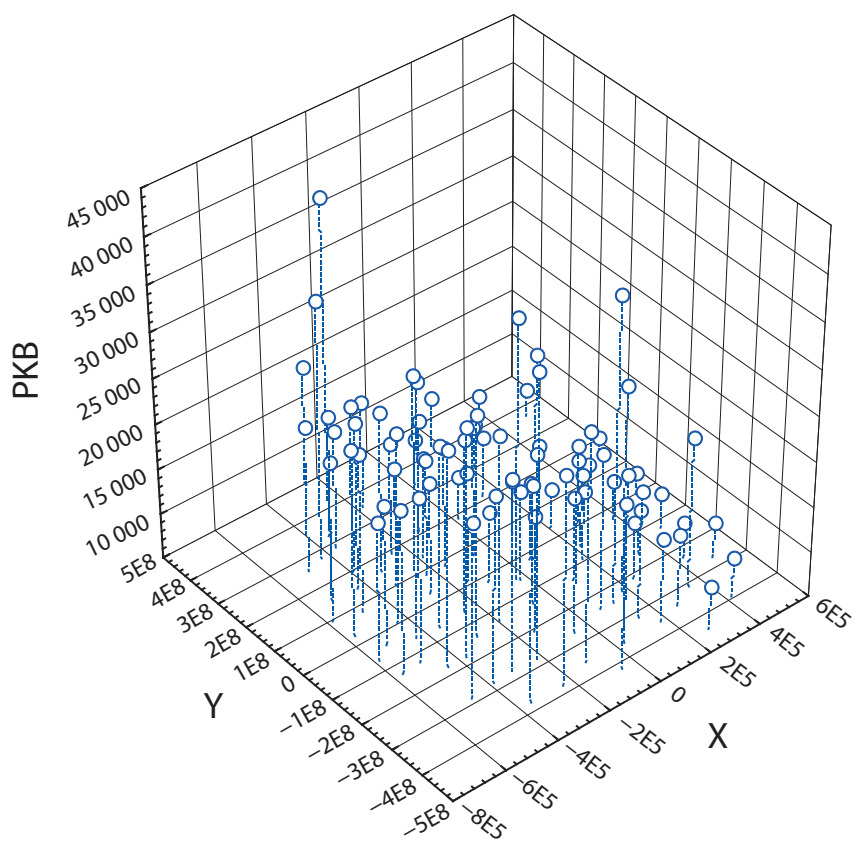

Wykres 1. Przestrzenny rozkład PKB per capita w 2004 roku Źródło: opracowanie własne.

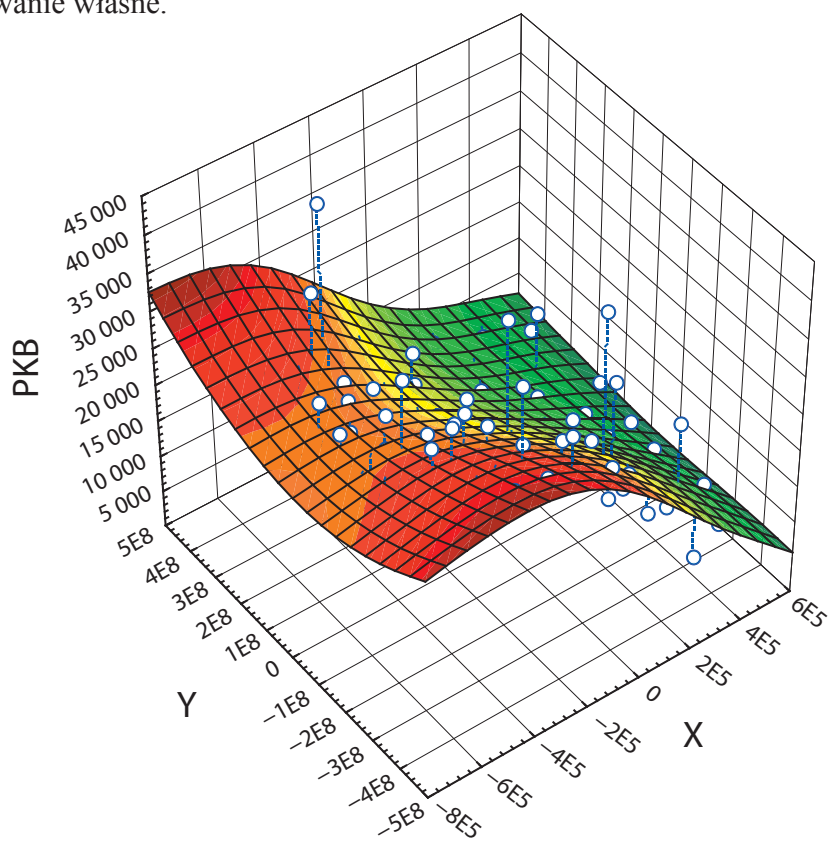

Wykres 2. Wyrównanie powierzchni trendu metodą mechaniczną Źródło: opracowanie własne. 
$\mathrm{W}$ analizie trendów przestrzennych pomocna jest graficzna prezentacja danych. Zatem wykres 1. przedstawia przestrzenny rozkład PKB per capita w 2004 roku.

Można zaobserwować pewną prawidłowość układu wartości w przestrzeni, chociaż obraz zakłócany jest wahaniami o charakterze stochastycznym. Wykres 2. przedstawia efekt tzw. mechanicznego wyodrębnienia trendu. Trend jest bardziej widoczny, co uzasadnia próbę dopasowania odpowiedniego modelu.

Empiryczny model liniowego trendu przestrzennego PKB przedstawia równanie (3), tj.:

$$
P \hat{K} B_{i}=\underset{(632,881)}{17925,6}-\underset{(0,0019)}{0,0177} x_{i}-\underset{(0,0027)}{0,0099} y_{i},
$$

$R^{2}=0,5354$.

Oszacowanie modelu trendu kwadratowego nie poprawiło w istotny sposób dopasowania do danych. Model z trendem trzeciego stopnia charakteryzował się nieco wyższym dopasowaniem, jednak również w tym wypadku poprawa nie była istotna. Zdecydowano się zatem na wybór modelu z trendem liniowym. Wykres 3. przedstawia dopasowanie trendu liniowego do analizowanych danych.

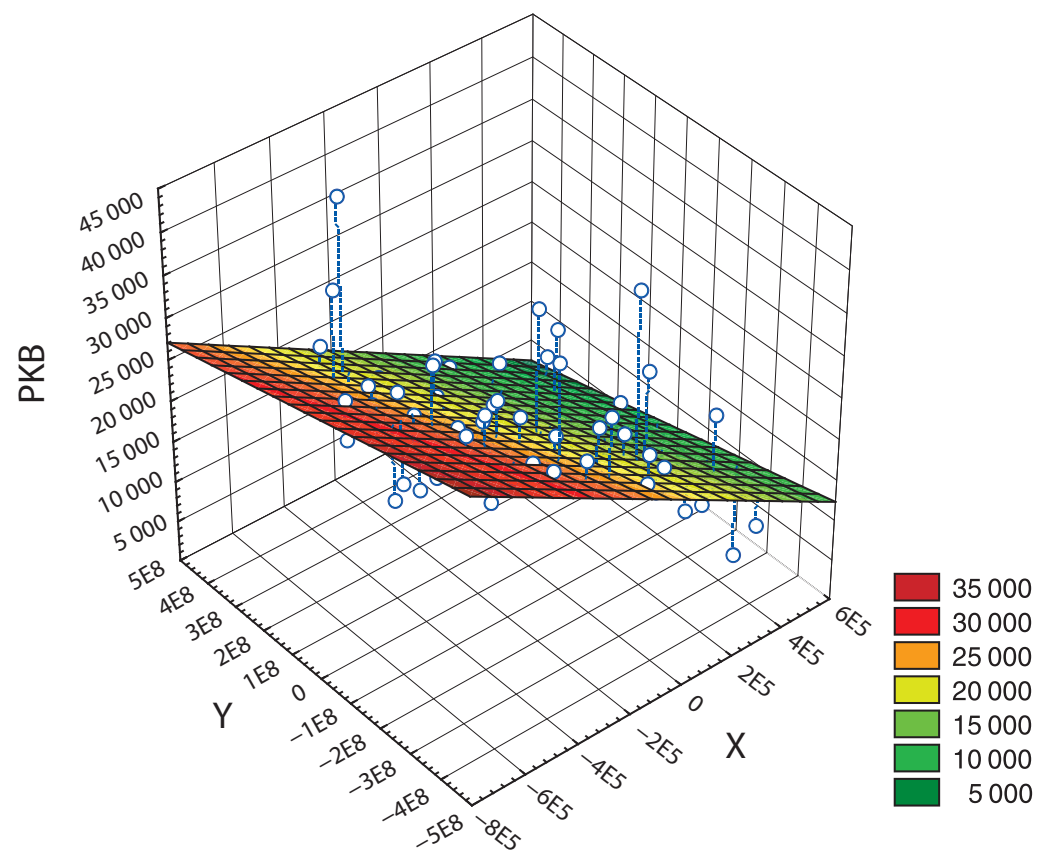

Wykres 3. Przestrzenny rozkład PKB wraz z dopasowaną powierzchnią trendu liniowego Źródło: opracowanie własne. 


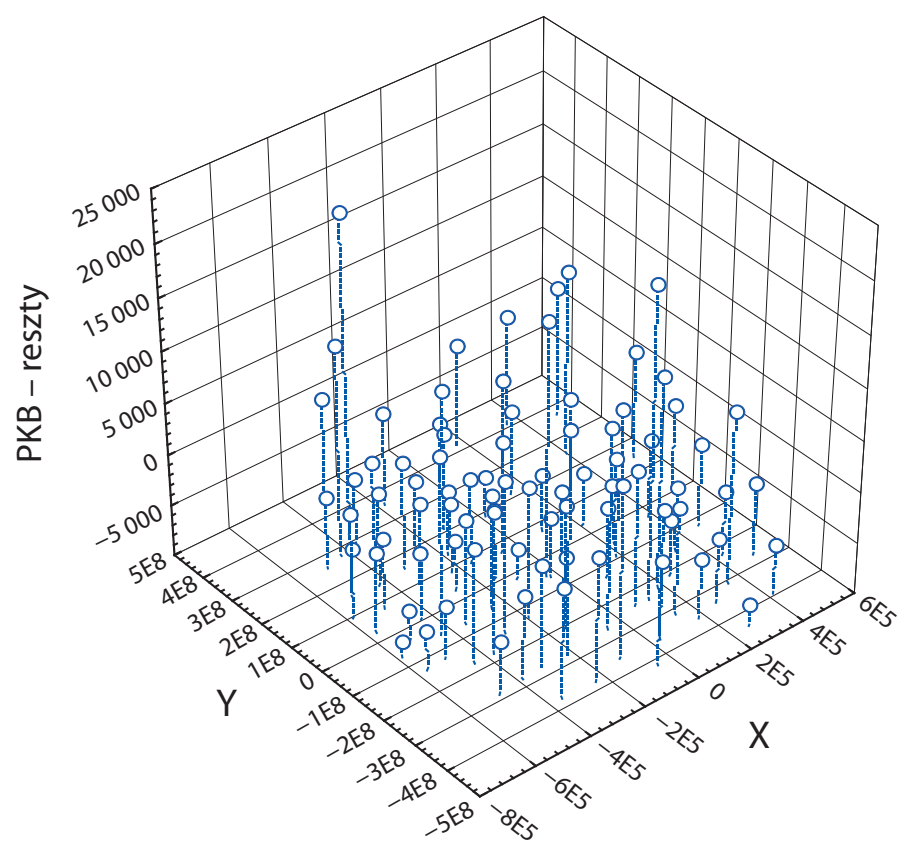

Wykres 4. Reszty po usunięciu trendu liniowego

Źródło: opracowanie własne.

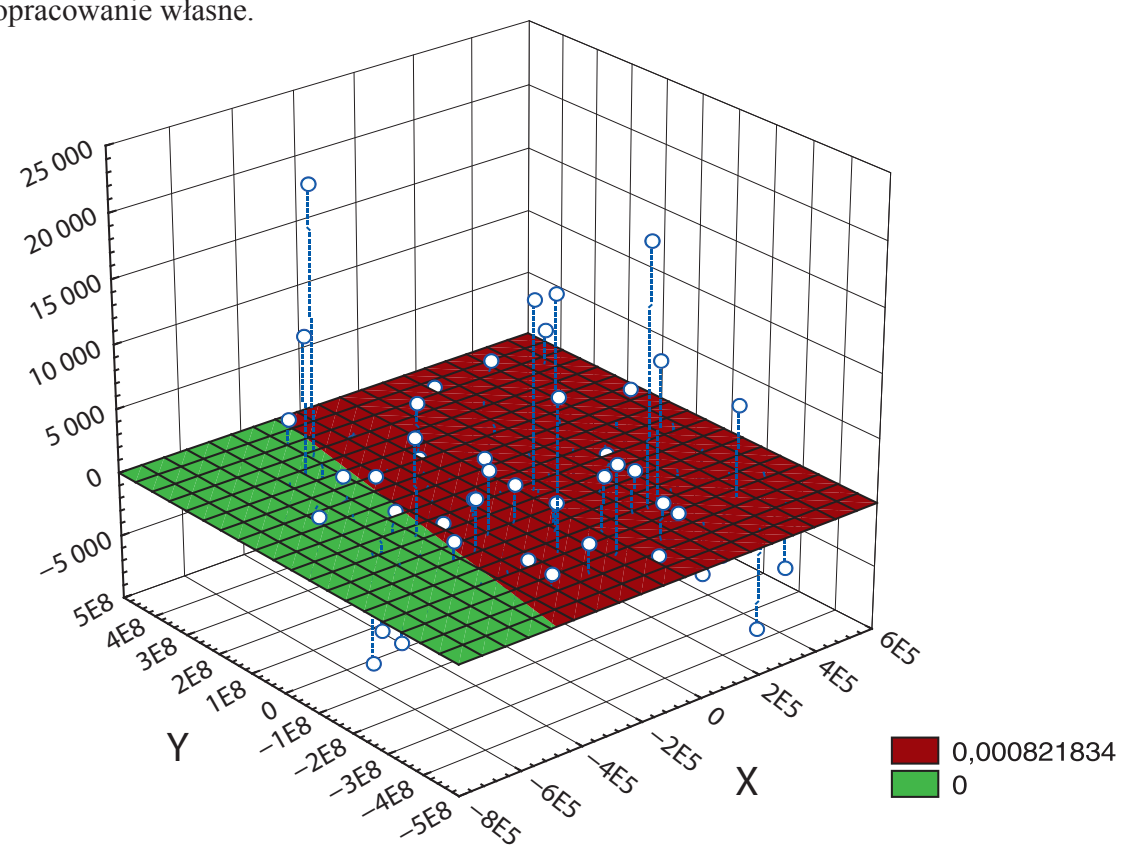

Wykres 5. Ilustracja braku trendu w resztach

Źródło: opracowanie własne. 
Dopasowanie trendu i uwzględnienie go explicite w modelu PKB jest jednoznaczne z filtracją badanego procesu przestrzennego. Po usunięciu trendu pozostają dane reprezentujące proces resztowy, który jest stacjonarny (jednorodny) ze względu na średnią. Wykres 4. przedstawia realizacje owego procesu resztowego.

Na wykresie 5. przedstawiono próbę dopasowania powierzchni trendu liniowego do otrzymanych reszt. Dopasowana powierzchnia pozioma do powierzchni $X Y$ potwierdza brak trendu, a zatem skuteczność przeprowadzonej filtracji.

Kolejnym krokiem na drodze badania struktury ekonomicznego procesu przestrzennego jest badanie autokorelacji

\section{CO TO JEST AUTOKORELACJA PRZESTRZENNA?}

Autokorelacja, jak sama nazwa wskazuje, oznacza korelację zmiennej z samą soba. W swej istocie autokorelacja przestrzenna jest podobna do autokorelacji czasowej. Jest jednak znacznie trudniejsza do analizy. Rozpatrując zależności w czasie, mamy do czynienia z naturalnym kierunkiem oddziaływania na linii: przeszłość $\rightarrow$ teraźniejszość $\rightarrow$ przyszłość. Tymczasem w przypadku przestrzeni zależności są wielokierunkowe.

Autokorelacja może być dodatnia lub ujemna. Autokorelacja dodatnia oznacza, że wartości zjawiska skupiają się w przestrzeni i obszary sąsiadujące są podobne. $Z$ kolei, w przypadku przestrzennej autokorelacji ujemnej obszary sąsiadujące różnią się pod względem badanej cechy bardziej, niż wynikałoby to $\mathrm{z}$ losowego rozłożenia wartości.

Koncepcje autokorelacji przestrzennej (dodatniej, ujemnej) oraz jej braku można przedstawić także graficznie, otrzymując tzw. wzorce przestrzenne autokorelacji (rys. 1).

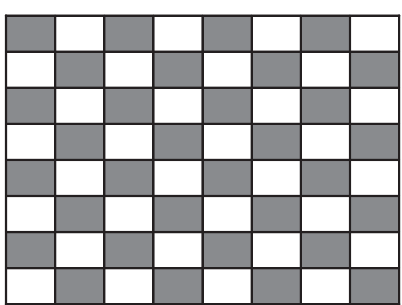

(a)

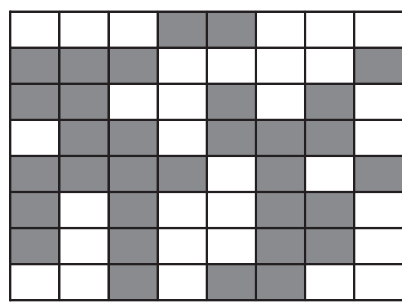

(b)

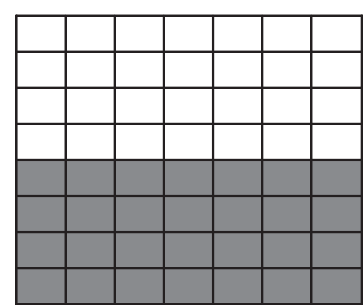

(c)

Rys. 1. Wzorzec przestrzenny autokorelacji: (a) autokorelacja ujemna, (b) brak autokorelacji, (c) autokorelacja dodatnia

Źródło: Longley i in. (2001), s. 10. 


\section{POMIAR AUTOKORELACJI PRZESTRZENNEJ}

Podstawą pomiaru autokorelacji przestrzennej jest określenie powiązań między jednostkami przestrzennymi (regionami). Przestrzenni sąsiedzi mogą być określani na wiele sposobów. Dwa powszechne podejścia są pokazane na rys. 2.
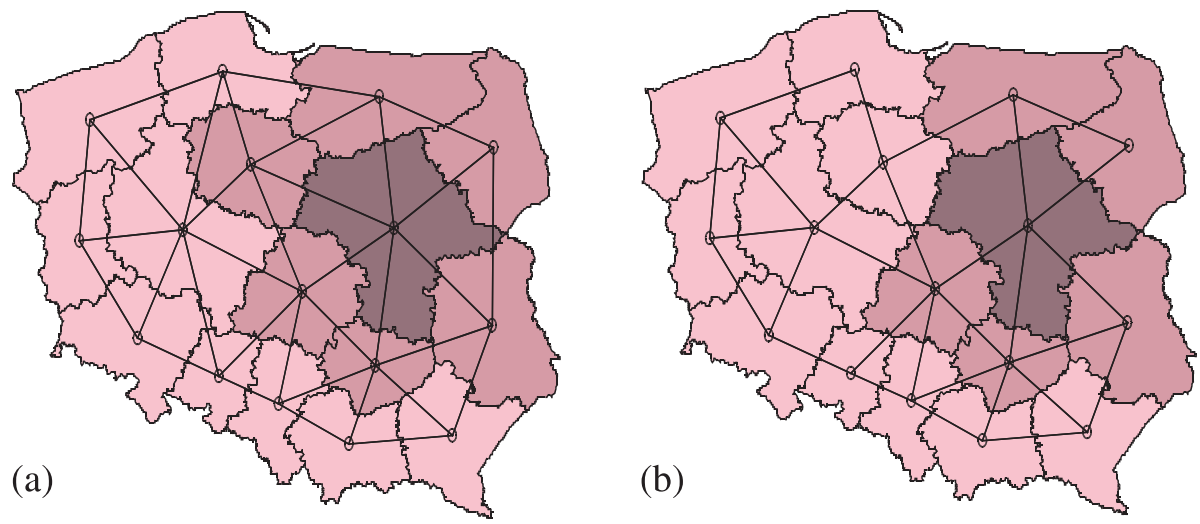

Rys. 2. Powiązania przestrzenne wg kryterium: (a) wspólnej granicy, (b) odległości w promieniu $d \mathrm{~km}$

Źródło: opracowanie własne.

Województwa są powiązane, jeśli posiadają wspólną granicę lub jeśli środki województw są oddalone o mniej, niż wynosi pewna odległość krytyczna $d$.

Kwantyfikacji powiązań przestrzennych dokonuje się za pomocą odpowiedniej macierzy wag $w_{i j}$. Macierz taką oznacza się przez W. Przy założeniu, że rozważa się $N$ regionów, macierze wag $\mathbf{W}$ są macierzami o wymiarach $N \times N$. Każdy wiersz macierzy $\mathbf{W}$ zawiera elementy niezerowe w kolumnach, które odpowiadają obiektom sąsiedzkim, określonym według przyjętego kryterium. Ponadto przyjmuje się, że elementy diagonalne macierzy $\mathbf{W}$ są zerami, co oznacza, że dany obiekt nie jest swoim sąsiadem.

Podstawowy typ macierzy powiązań wykorzystywanych w analizach przestrzennych stanowią macierze konstruowane według kryterium wspólnej granicy. Punktem wyjścia jest binarna macierz sąsiedztwa $\mathbf{S}$, o elementach:

$$
s_{i j}=\left\{\begin{array}{ccc}
1, & \text { jeśli obiekt } i \text { jest sąsiadem } j \\
0, & \mathrm{w} \text { pozostałych przypadkach. }
\end{array}\right.
$$

Następnie normuje się wiersze w $\mathbf{S}$ w taki sposób, aby sumy elementów w każdym wierszu były równe jedności. (Operację tę nazywa się czasami standaryzacją wierszami). Niech zatem 


$$
\mathbf{D}=\operatorname{diag}\left\{d_{i}\right\} \text {, gdzie } d_{i}=\frac{1}{\sum_{j=1}^{N} s_{i j}}, i=1,2, \ldots, N \text {. Wtedy } \mathbf{W}=\mathbf{D S} \text { i } \sum_{j} w_{i j}=1 \text {. }
$$

Podstawową miarą autokorelacji przestrzennej jest statystyka Morana $I$, którą można wyrazić następującym wzorem:

$$
I=\frac{n}{\sum_{i} \sum_{j} w_{i j}} \frac{\sum_{i} \sum_{j} w_{i j}\left(x_{i}-\bar{x}\right)\left(x_{j}-\bar{x}\right)}{\sum_{i}\left(x_{i}-\bar{x}\right)^{2}},
$$

gdzie:

$x_{i}$ - obserwacja zjawiska w regionie $i$,

$\bar{x}$ - średnia wartość zjawiska,

$w_{i j}$ - elementy odpowiedniej macierzy wag.

Po obliczeniu statystyki $I$, przy założeniu określonego wzorca rozkładu danych przestrzennych (normalny lub losowy) dokonuje się oceny istotności tejże statystyki.

\section{Przykład empiryczny (c.d.)}

Zbadano autokorelację przestrzenną dla reszt z modelu (3). W tym celu policzono wartość statystyki Morana I oraz oceniono jej istotność, a także sporządzono wykres punktowy tej statystyki. Dokonano interpretacji otrzymanych wyników.

Statystyka Morana I przy założeniu losowości

Tabela 1. Testowanie autokorelacji przestrzennej - wariant I

\begin{tabular}{|c|c|c|}
\hline$I$ & $\mathrm{E}(()$ & $\operatorname{Var}(()$ \\
\hline 0,164096 & $-0,012048$ & 0,004647 \\
$\begin{array}{c}|c| \\
\text { Standaryzowana statystyka / } \\
2,584\end{array}$ & \multicolumn{2}{|c|}{$p$-value $=0,0048$} \\
\hline
\end{tabular}

Źródło: opracowanie własne.

Statystyka Morana $I$ przy założeniu normalności

Tabela 2. Testowanie autokorelacji przestrzennej - wariant II

\begin{tabular}{|c|c|c|}
\hline I & $\mathrm{E}(()$ & $\operatorname{Var}(()$ \\
\hline 0,164096 & $-0,012048$ & 0,004868 \\
$\begin{array}{c}\text { Standaryzowana statystyka / } \\
2,5247\end{array}$ & \multicolumn{2}{|c|}{$p$-value $=0,00579$} \\
\hline
\end{tabular}

Źródło: opracowanie własne. 


\section{Wnioski}

W obu przypadkach statystyka Morana jest istotna statystycznie. Wartość statystyki wskazuje na niezbyt wysoką autokorelację dodatnią. Dodatnia wartość $I$ oznacza, że wartości PKB per capita w regionach sąsiedzkich są do siebie podobne. Wykres 6. stanowi graficzną ilustrację stwierdzonej autokorelacji przestrzennej. Nachylenie linii ciągłej odpowiada wielkości autokorelacji.

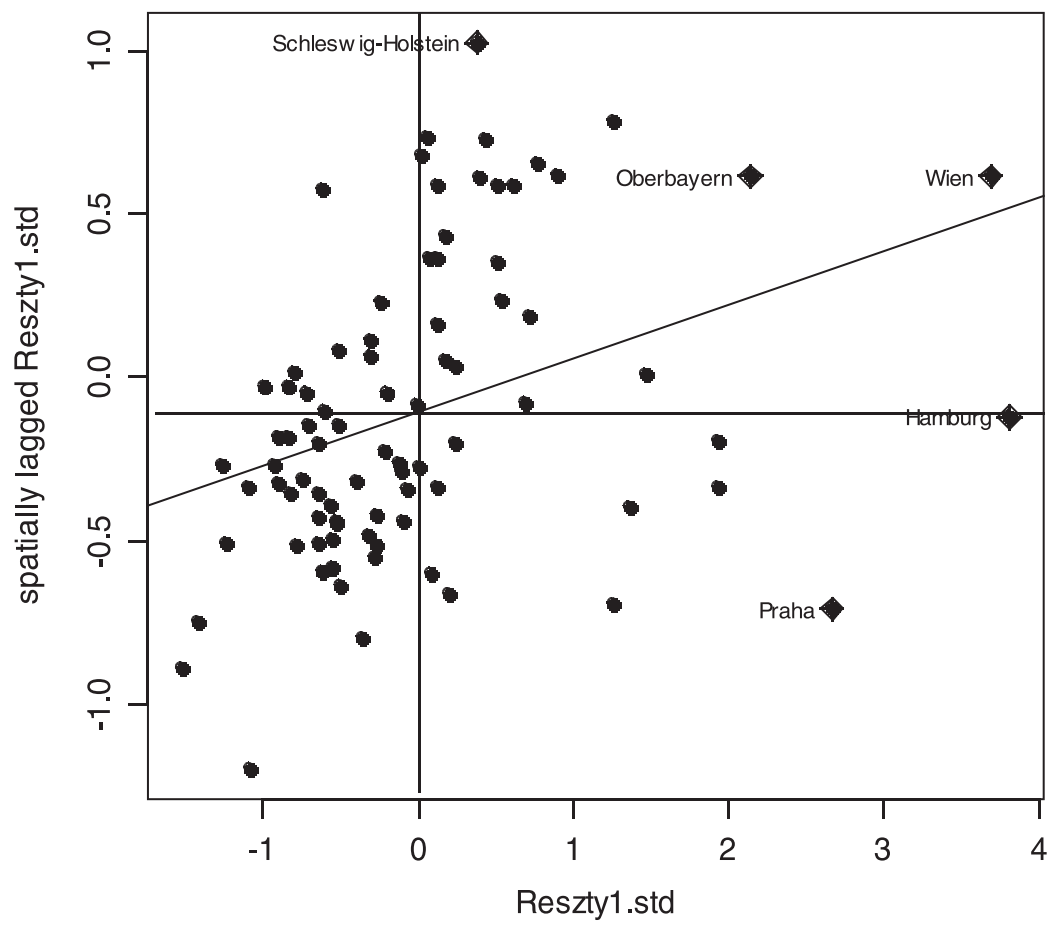

Wykres 6. Wykres punktowy statystyki Morana Źródło: obliczenia własne.

Wykrycie autokorelacji $\mathrm{w}$ toku badania struktury procesu przestrzennego skutkuje potrzebą rozbudowania modelu, np.:

$$
Y(\mathbf{s})=P(\mathbf{s})+\rho \mathbf{W} Y(\mathbf{s})+\varepsilon(\mathbf{s}) .
$$

Można zadać kolejne pytanie, czy jest to ostateczna specyfikacja? Wątpliwość może budzić ograniczenie uwagi do autozależności pierwszego rzędu, co wyraża się uwzględnieniem powiązań przestrzennych jedynie pomiędzy najbliższymi sąsiadami. 


\section{KORELOGRAM PRZESTRZENNY}

Do badania zakresu przestrzennego autokorelacji wykorzystuje się korelogram przestrzenny. W tym wypadku korelogram może być konstruowany za pomocą dwóch metod. Pierwsza metoda polega na wykorzystaniu klasycznego współczynnika korelacji dla każdego ustalonego przesunięcia przestrzennego. Druga zaś polega na obliczeniu odpowiednich statystyk Morana. W prezentowanym przykładzie zastosowano obie metody.

Wykres 7. przedstawia korelogramy szóstego rzędu. Tabele 3. i 4. z kolei przedstawiają wartości współczynników autokorelacji oraz informacje potrzebne do oceny ich istotności.
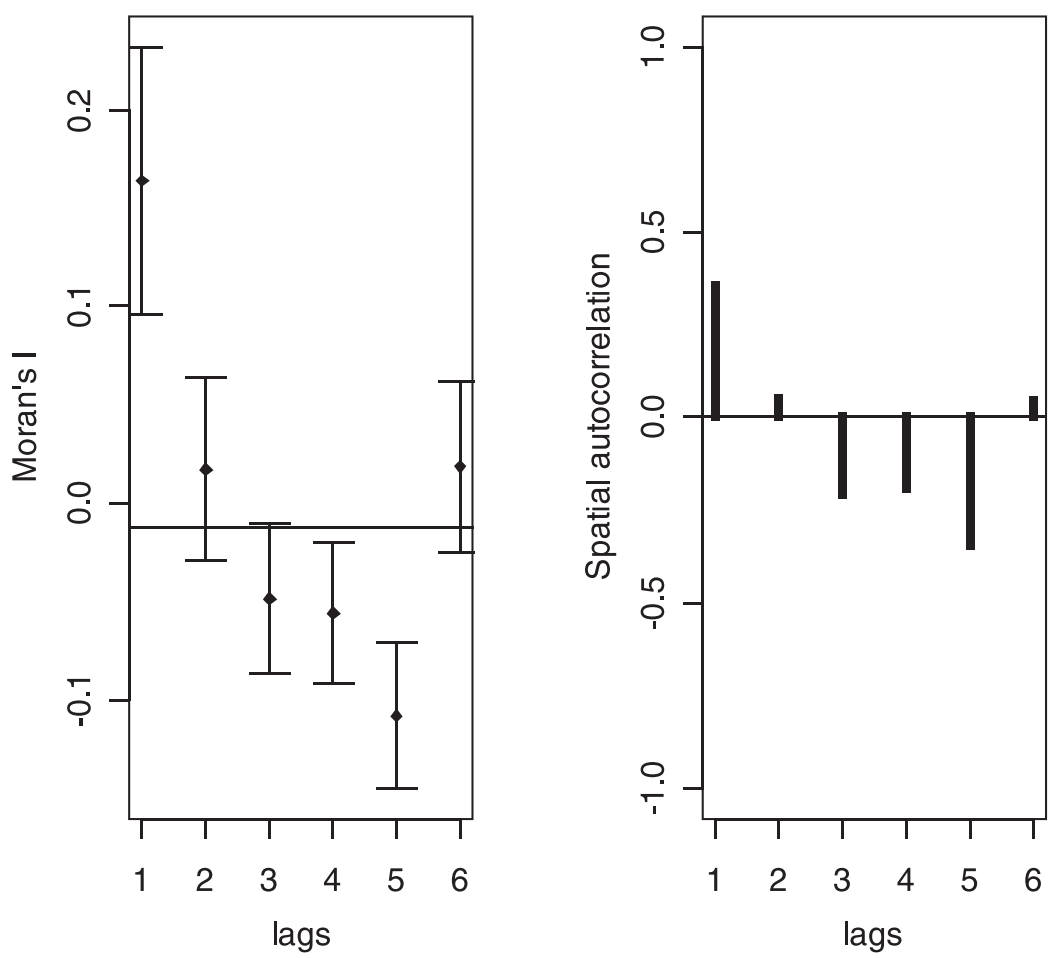

Wykres 7. Przestrzenne korelogramy szóstego rzędu Źródło: obliczenia własne. 
Tabela 3. Wyniki badania istotności współczynników I Morana

\begin{tabular}{|c|c|c|c|c|c|}
\hline Lag & $I$ & $E()$ & $\operatorname{Var}(()$ & \multicolumn{1}{|c|}{ Zl } & $p$-value \\
\hline 1 & 0,16409571 & $-0,01204819$ & 0,004646915 & 2,5839567 & 0,00488373 \\
2 & 0,01731291 & $-0,01204819$ & 0,002137843 & 0,6350157 & 0,26270902 \\
3 & $-0,04846420$ & $-0,01204819$ & 0,001481503 & $-0,9461093$ & 0,17204641 \\
4 & $-0,05598770$ & $-0,01204819$ & 0,001305207 & $-1,2162296$ & 0,11194979 \\
5 & $-0,10787250$ & $-0,01204819$ & 0,001391760 & $-2,5685832$ & 0,00510579 \\
6 & 0,01850673 & $-0,01204819$ & 0,001858531 & 0,7087553 & 0,23923809 \\
\hline
\end{tabular}

Źródło: obliczenia własne.

Tabela 4. Wyniki badania istotności przestrzennych współczynników korelacji

\begin{tabular}{|c|c|c|c|c|}
\hline Lag & $r$ & $n$ & Statystyka & $p$-value \\
\hline 1 & 0,3577530 & 428 & 7,907272 & 0,000000 \\
2 & 0,0541818 & 844 & 1,574518 & 0,115743 \\
3 & $-0,2057987$ & 1140 & $-7,094330$ & 0,000000 \\
4 & $-0,1926609$ & 1230 & $-6,880280$ & 0,000000 \\
5 & $-0,3447796$ & 1162 & $-12,509800$ & 0,000000 \\
6 & 0,0470603 & 978 & 1,471843 & 0,141386 \\
\hline
\end{tabular}

Źródło: obliczenia własne.

Według pierwszej metody za istotne należy uznać współczynniki pierwszego oraz piątego rzędu, natomiast według metody drugiej - współczynniki pierwszego, trzeciego, czwartego oraz piątego rzędu. Niewykluczone zatem jest występowanie korelacji pomiędzy dalszymi sąsiadami w zakresie wartości badanego procesu.

\section{SPECYFIKACJA EKONOMETRYCZNEGO MODELU PRZESTRZENNEGO}

Analiza struktury i własności przestrzennego procesu PKB per capita w 2004 roku na wyodrębnionym obszarze pozwoliła sformułować następującą hipotezę modelową dla tego procesu:

$$
P K B_{i}=\theta_{0,0}+\theta_{1,0} x_{i}+\theta_{0,1} y_{i}+\rho \mathbf{W}\left(P K B_{i}\right)+\varepsilon_{i} .
$$

Wyniki oszacowania parametrów i weryfikacji modelu (6) przedstawia tabela 5.

Tabela 5. Zestawienie wyników szacowania i weryfikacji modelu (6)

\begin{tabular}{|c|c|c|c|c|}
\hline Parametry & Szacunki parametrów & Błędy standardowe & Statystyki & $p$-value \\
\hline$\theta_{0,0}$ & 10898 & 2505,1 & 4,3505 & 0,00001 \\
$\theta_{1,0}$ & $-0,01099$ & 0,00286 & $-3,8526$ & 0,00012 \\
$\theta_{0,1}$ & $-0,00579$ & 0,00276 & $-2,0943$ & 0,03623 \\
\hline$\rho=0,40379$ & \\
test $L R: 6,5691, p$-value $=0,01037$ & Autokorelacja reszt \\
test $L R: 0,00523, p$-value $=0,94237$ &
\end{tabular}

Źródło: obliczenia własne. 


\section{Wnioski}

- Otrzymany model empiryczny charakteryzuje się istotnymi parametrami.

- Reszty nie wykazują autokorelacji.

- Uwzględnienie w strukturze autoregresyjnej jedynie zależności pierwszego rzędu jest wystarczające.

\section{PODSUMOWANIE}

Celem artykułu było wskazanie na walory poznawcze badania struktur i własności przestrzennych procesów ekonomicznych. Poznanie owych własności pozwala $\mathrm{z}$ jednej strony nadać odpowiednią interpretację systematycznym zmianom wartości tych zjawisk w przestrzeni oraz autozależnościom przestrzennym, z drugiej zaś prowadzi do specyfikacji modeli przestrzennych o odpowiednich własnościach.

\section{LITERATURA}

Kopczewska K. (2006), Ekonometria i statystyka przestrzenna z wykorzystaniem programи R CRAN, CeDeWu Sp. Z o. o.

Longley P., Goodchild M., Maguire D., Rhind D. (2001), Geographic Information Systems and Science, John Wiley \& Sons, New York.

Schabenberger O., Gotway A. C. (2005), Statistical Methods for Spatial Data Analysis, Champion \& Hall/CRC, New York.

\section{ANALYSIS OF THE STRUCTURE OF ECONOMIC SPATIAL PROCESSES ON THE EXAMPLE OF GDP IN CHOSEN EUROPEAN COUNTRIES}

A b stract. The purpose of the paper is to show the procedure of modelling of the spatial processes, which takes into account the deterministic and stochastic structure of these processes.

In the introduction a general structure of components of the spatial economic process was presented. The property of homogeneity (stationarity) of the spatial processes was discussed as well.

In the section 2 the notion of the spatial trend was formulated and the chosen models of the spatial trends were presented. There was also demonstrated an empirical example of fitting the adequate model of the spatial trend.

In the section 3 the attention was focused on the phenomenon of the spatial autocorrelation. The structures of spatial connections most often used for investigating the 
autocorrelation were pointed out. The appropriate measure of the spatial autocorrelation was given and an empirical example of investigating the autocorrelation was presented. The analysis of the spatial autocorrelation was realized in particular basing on the readings of the so-called spatial correlogram.

In the section 4 the model of the spatial process, which takes into consideration the previous settlements as regards its internal structure, was proposed.

The section 5 includes a short recapitulation.

The results of the investigation confirmed the necessity of determining the internal structures while modelling the spatial economic processes.

Ke yw ords: spatial trend, spatial autocorrelation, connectivity matrix, correlogram. 